\title{
Effect of fermentation length and varieties on the qualities of corn starch (Ogi) production
}

\author{
Adegunwa, M.O' ${ }^{1}$, Alamu, E.O' ${ }^{2}$ Bakare, H.A ${ }^{1}$ and Godwin, P.O ${ }^{3}$ \\ ${ }^{1}$ Department of Foodservice and Tourism. University of Agriculture, Abeokuta, Nigeria \\ ${ }^{2}$ International Institute of Tropical Agriculture, Ibadan, Nigeria. \\ ${ }^{3}$ Department of Home Economics and Hotel Management, Tai Solarin University of \\ Education, ljebu-Ode, Nigeria. \\ Corresponding author: Adegunwa, M. O. (moadegunwa@gmail.com)
}

\begin{abstract}
Ogi produced from two varieties of maize (White and yellow) at different length of fermentation using same method of processing were analyzed for chemical, functional, pasting and sensory qualities. For varietals influence, there were significant different in protein (10.05- $10.55 \%)$, Ash (0.86- $1.10 \%)$, moisture content (8.88- 10- $33 \%)$. Functional properties of water absorption capacity ranged between $66.28-68.77 \%$, for swelling power $8.08-9.88 \%$, for solubility $7.02-$ 8.56 for Bulk density 0.623- 0.66, for amylose 17.66- $19.25 \%$. Pasting properties ranged between 143.58- 176 RVU for peak viscosity, trough 115.42 - 132.42 RVU, breakdown 28.1743.58 RVU, setback 31.75- 53.17 RVU. There were significant difference $(p<0.05)$ in the sensory qualities of Ogi powder samples except for texture. Result of sensory evaluation shows that Ogi made from yellow variety of fermentation length of 3 days are more acceptable than Ogi made from white variety of fermentation length of 5 days. Therefore yellow Ogi has highest percentage protein, water absorption capacity, odour, colour, texture and overall acceptability by the panelist.
\end{abstract}

Keywords: Corn, Ogi, Properties, Varieties, Fermentation.

\section{INTRODUCTION}

Maize is the third most important cereal in the world after rice and wheat and ranks fourth after millet and rice in Nigeria. The large proportion of the carbohydrate in field corn is stored as starch (Adegoke and Adeyemi, 1994).

Ogi (corn starch) is the product obtained by fermentation of corn. Ogi (Maize gruel) is obtained by cooking corn starch. This is usually eaten hot and with bean balls. It serves as a popular break fast food in Nigeria.

There are so many problems arising from fermentation of Ogi (corn starch) and this may include, deriving a complete sour taste which may result in over fermentation due to the conception of people, varietal problems among many others. Also different length of fermentation can affect the final product. Therefore, there is need to determine the effect of fermentation length and varieties on Ogi production

\section{MATERIALS AND METHODS}

Maize (white and yellow maize) was obtained from ljebu- Igbo market.
Processing of Ogi: Ogi is made from dried corn. Ogi (corn starch) is the product obtained by fermentation of corn. The process essentially consists of soaking the maize in water for one to seven days. The softened corn is washed and ground in a mechanized mill. The ground materials is rinsed with water and passed through a sleeve (Muslin cloth) to remove parts of the hull. The filtrate almost pure starch is placed in pots of water to settle and cover it up completely (Adegoke and Adeyemi, 1994).

Analytical determinations: The moisture, protein, Ash and fat contents of the samples were determined using the AOAC (2004) method. The starch and total sugars content were determined using a colorimetric method described earlier in Onitilo et al.2007. Absorbance was read at $490 \mathrm{~nm}$ using a spectrophotometer (model Spectronic 601, Milton Roy Company, USA). The amylose content was determined using the method of Williams et al (1970) involving the preparation of stock iodine solution and iodine reagent. Absorbance was read using a spectrophotometer at $620 \mathrm{~nm}$. A blank was used to standardize the spectrophotometer.

Swelling Power and Solubility was determined by the Takashi and Seib (1988) method. Water Absorption 
Capacity (WAC) was determined using the method described by Sosulski (1962).

Pasting properties of flour was characterized using Rapid Visco Analyser (RVA) Model 3C, Newport Scientific PTY Ltd., Sydney) as described by Delcour et al. (2000) and Sanni et al., (2004). Five gram (5g) of sample was accurately weighed into a weighing vessel. $25 \mathrm{ml}$ of distilled water was dispensed into a new test canister. Sample was transferred onto the water surface in the canister, after which the paddle was placed into the canister. The blade was vigorously joggled up and down through the sample ten times or more until no flour lumps remained neither on the water surface nor on the paddle. The paddle was placed into the canister and both were inserted firmly into the paddle coupling so that the paddle is properly centered. The measurement cycle was initiated by depressing the motor tower of the instrument. The test was then allowed to proceed and terminate automatically.

Statistical Analysis: The data generated were analyzed using Statistical Analysis Systems version 9.1 SAS (2003) software package. Significance of treatment means was tested at $5 \%$ probability level

\section{RESULTS AND DISCUSSIONS}

The chemical composition of Ogi meal obtained from different varieties and fermentation length are shown in Table 1. The protein content ranged between 10.05 and $10.55 \%$. Ogi white has low moisture content, ash and fibre irrespective of the days used for their fermentation. This means that Yellow Ogi has good protein source than White Ogi. Hence, there exist a significant difference $(p<0.05)$ for variables analyzed except for fat and fibre in which there was no significant difference $(p>0.05)$ in both white and yellow Ogi.

Table 1: Chemical Properties of Ogi

\begin{tabular}{|l|l|l|l|l|l|}
\hline Ogi Sample & Protein $\%$ & Fat \% & Ash \% & Fibre \% & M.C $\%$ \\
\hline One day fermented white Ogi & 10.05 & 1.01 & 0.86 & 1.03 & 8.88 \\
\hline One day fermented yellow Ogi & 10.15 & 1.02 & 0.92 & 1.08 & 8.97 \\
\hline Three days fermented white Ogi & 10.22 & 1.04 & 1.02 & 1.19 & 9.75 \\
\hline Three days fermented yellow Ogi & 10.50 & 1.06 & 1.05 & 1.22 & 9.83 \\
\hline Five days fermented white Ogi & 10.38 & 1.07 & 1.08 & 1.25 & 10.25 \\
\hline Five days fermented yellow Ogi & 10.55 & 1.15 & 1.10 & 1.33 & 10.33 \\
\hline Mean square & 34.133 & 6.521 & 31.189 & 5.350 & 24.656 \\
\hline F ratio & 22.308 & 1.849 & 17.212 & 1.059 & 8.943 \\
\hline Significant & $0.000^{*}$ & 0054 & $0.000^{*}$ & 0.400 & $0.000^{*}$ \\
\hline
\end{tabular}

Each value represent mean of three replicates

Table 2 shows the results of Water Absorption Capacity (WAC) of Ogi samples which ranged between $66.28 \%$ and $68.77 \%$ with yellow Ogi having the highest WAC irrespective of the day (s) used for its fermentation. There exist significant differences at $p<0.05$ between the samples. This entails that yellow Ogi is better than white Ogi because of its higher percentage in WAC.

The result of the swelling power of Ogi at different fermentation length and varieties are shown in Table 2. There is an increase in the value of the swelling power at range $8.08 \%$ and $9.88 \%$. There is a significant different $(p<0.05)$ in both white and yellow Ogi. Onitilo (2007) have suggested that the swelling power granules reflect the extent of the association forces within the granules. Swelling power and solubility of the starches provide evidence of non covalent bonding between molecules within the starch granules. Swelling is a factor of ratio of amylose to amylopectin, the characteristics of each fraction in terms of molecular weight - distribution degree length of branching and confirmation. The presence of naturally occurring non- carbohydrates such a lipid is also an important factors. The formation of amylase lipid complexes can restrict swelling and solubilization.

The value of solubility of the samples of Ogi are shown in the Table 2, an increase in solubility was noticed in all samples. Since leaching of amylose as responsible for most of the solubility of starch based product (Dengate, 1981), higher solubility in yellow Ogi implies that it is lesser in leaching than Ogi white, leaching is enhanced by hydrolysis of amylase during soaking or hindered by new internal bounding (Numfor et al, 1996). An increase in solubility at 
different temperature implied more amylose was lost during heating. Solubility therefore, is a function of processing and reconstitution. Hence, the higher the solubility, the more the Ogi reconstitute well in water. There is a significant different between yellow and white Ogi samples at $(p<0.05)$.

Table 2 also shows the percentage of bulk density of white Ogi and yellow Ogi. The value ranged between $0.62 \%$ and $0.66 \%$ with white Ogi lower in bulk density than yellow Ogi. Bulk density of yellow Ogi and white Ogi increased as fermentation increases. Hence,

Table 2: Functional Properties of Ogi there is a significant difference $(p<0.05)$ in the bulk density of white Ogi and yellow Ogi samples.

The result of amylose correspond with the works of Dengate (1981) that amylose content of Ogi increase the WAC, since leaching of amylose is responsible for most of the solubility of starch based product. The amylose contents of both samples of Ogi ranged between $17.66 \%$ and $19.25 \%$ with yellow Ogi having the highest amylose irrespective of the days used for their fermentation process. There exists a significant difference at $p<0.05$ between the samples.

\begin{tabular}{|l|c|c|c|c|c|}
\hline Ogi Sample & $\begin{array}{c}\text { Water } \\
\text { Absorption } \\
\text { Capacity } \%\end{array}$ & $\begin{array}{c}\text { Swelling } \\
\text { power \% }\end{array}$ & Solubility \% & Bulk density & Amylose \% \\
\hline One day fermented white Ogi & 66.28 & 8.08 & 7.02 & 0.62 & 17.66 \\
\hline One day fermented yellow Ogi & 66.44 & 8.12 & 7.17 & 0.63 & 18.06 \\
\hline Three days fermented white Ogi & 67.08 & 8.25 & 7.22 & 0.64 & 18.22 \\
\hline Three days fermented yellow Ogi & 67.66 & 9.11 & 8.24 & 0.64 & 18.44 \\
\hline Five days fermented white Ogi & 67.81 & 9.22 & 8.33 & 0.65 & 18.92 \\
\hline Five days fermented yellow Ogi & 68.77 & 9.88 & 8.56 & 0.66 & 19.25 \\
\hline Mean square & 19.83 & 14.22 & 21.16 & 8.93 & 19.52 \\
\hline F ratio & 26.11 & 8.36 & 22.22 & 2.16 & 16.74 \\
\hline Significant & $0.000^{*}$ & $0.000^{*}$ & $0.000^{\star}$ & 0.029 & $0.000^{\star}$ \\
\hline
\end{tabular}

Each value represent mean of three replicates.

Table 3 shows the pasting properties of white and yellow Ogi. Peak viscosity increased as fermentation increases. It ranged between 143.58 and 174.00 RVU. The highest peak viscosity was recorded for yellow Ogi while the least was recorded for white Ogi. Peak viscosity indicates the water binding capacity of the starch or mixture. It is often correlated with final product quality. The peak occurs of the equilibrium point between swelling causing an increase in viscosity, rupture and alignment causing its decrease.

The value of peak time range between 5.08 and 5.47 min. white Ogi has the least peak time and yellow Ogi sample recorded the highest peak time. There is a significant different $(p<0.05)$ among the samples.

The pasting temperature value ranged between 63.95 and $65.55{ }^{\circ} \mathrm{C}$ with yellow and white Ogi having the highest and lowest respectively. A significant different exist among the samples $(p<0.05)$. The temperature at the onset of rise in viscosity is known as the pasting temperature. The pasting temperature provides an indication of the minimum temperature required to cook a given sample, which can have implication on the stability of other components in a formula, actually swell over a range of temperature, indicating their heterogeneity of behaviours.

The values of breakdown ranged between 28.17 and 43.58 RVU. Final viscosity ranged between 147.17 and $183.58 \mathrm{RVU}$, set back values ranged between 31.75 and $53.17 \mathrm{RVU}$, trough ranged between 115.42 and $132.42 \mathrm{RVU}$. The rate of increase in fermentation depend on the temperature and degree of mixing applied to the mixture and the nature of the materials itself

Breakdown indicates the ability of the materials to form a viscosity paste or gel after boiling and cooling there exist significant different $(p<0.05)$ among the sample.

Setback has been correlated with texture of various products, high setback is also associated with syneresis during freeze thaw cycles for example, and substituted starches are commonly used where this presents a quality defect. Setback is measured as the different between breakdown and peak viscosity. 
Am. J. Food. Nutr, 2011, 1(4): 166-170

Table 3: Pasting Properties of Ogi

\begin{tabular}{|l|l|l|l|l|l|l|l|}
\hline Ogi Sample & $\begin{array}{l}\text { Peak } \\
\text { Viscosity } \\
\text { RVU }\end{array}$ & $\begin{array}{l}\text { Troug } \\
\text { h RVU }\end{array}$ & $\begin{array}{l}\text { Break } \\
\text { down } \\
\text { RVU }\end{array}$ & $\begin{array}{l}\text { Final } \\
\text { Viscosity } \\
\text { RVU }\end{array}$ & $\begin{array}{l}\text { Setback } \\
\text { RVU }\end{array}$ & $\begin{array}{l}\text { Peak } \\
\text { time.(min) }\end{array}$ & $\begin{array}{l}\text { Temp } \\
{ }^{\circ} \mathbf{C} .\end{array}$ \\
\hline One day fermented white Ogi & 143.58 & 115.42 & 28.17 & 147.17 & 31.75 & 5.08 & 63.95 \\
\hline One day fermented yellow Ogi & 148.58 & 115.50 & 30.42 & 152.92 & 37.17 & 5.12 & 63.95 \\
\hline Three days fermented white Ogi & 149.75 & 118.17 & 31.58 & 163.50 & 37.42 & 5.15 & 64.85 \\
\hline Three days fermented yellow Ogi & 156.33 & 119.25 & 34.25 & 164.08 & 45.33 & 5.15 & 65.05 \\
\hline Five days fermented white Ogi & 158.50 & 126.92 & 37.08 & 171.75 & 52.50 & 5.25 & 65.25 \\
\hline Five days fermented yellow Ogi & 174 & 132.42 & 43.58 & 183.58 & 53.17 & 5.47 & 65.55 \\
\hline Mean square & 31.104 & 11.814 & 30.667 & 6.004 & 21.822 & 6.311 & 31.667 \\
\hline F ratio & 25.025 & 4.169 & 23.703 & 1.193 & 8.636 & 24.49 & 22.703 \\
\hline Significant & $0.000^{*}$ & $0.000^{*}$ & $0.000^{*}$ & 0.301 & $0.000^{*}$ & 0.045 & $0.000^{*}$ \\
\hline
\end{tabular}

Each value represent mean of the three replicate.

The results of sensory evaluation of Ogi (pap) were shown in Table 4. The responses were based on panelist perception or quality understanding about how best they like pap samples. There was no significant different ( $p>0.05)$ among the samples in the sensory scores for odour, texture, colour, taste and overall acceptability. Pap sample made from

yellow Ogi recorded the highest level for odour, colour, taste and overall acceptability than that made from white Ogi by the panelist, moreover, there was no different in the level of acceptability of various pap samples. Hence, yellow Ogi is chosen to be the best variety because of its good quality and nutritional advantage.

Table 4: Sensory Qualities of Ogi (Pap)

\begin{tabular}{|l|l|l|l|l|l|}
\hline Ogi Sample & Odour & Texture & Colour & Taste & $\begin{array}{l}\text { Overall } \\
\text { acceptability }\end{array}$ \\
\hline One day fermented white Ogi & 2.89 & 4.47 & 2.21 & 3.79 & 2.20 \\
\hline One day fermented yellow Ogi & 4.00 & 4.63 & 3.11 & 4.50 & 4.26 \\
\hline Three days fermented white Ogi & 4.85 & 4.79 & 5.16 & 4.84 & 4.44 \\
\hline Three days fermented yellow Ogi & 5.89 & 4.84 & 5.53 & 5.05 & 4.67 \\
\hline Five days fermented white Ogi & 6.27 & 5.11 & 6.64 & 6.16 & 5.65 \\
\hline Five days fermented yellow Ogi & 7.85 & 5.37 & 6.89 & 7.87 & 6.36 \\
\hline Mean square & 4.79 & 1.15 & 7.31 & 1.03 & 2.07 \\
\hline F ratio & 0.09 & 0.27 & 1.63 & 1.72 & 0.43 \\
\hline Significant & 0.770 & 0.609 & 0.204 & 0.192 & 0.515 \\
\hline
\end{tabular}

Each value represent mean of three replicates.

\section{CONCLUSION}

The study has shown that a variety has significant effects on the qualities of Ogi especially in protein, water absorption capacity, amylose, moisture content and ash.

Result of sensory evaluation shows that Ogi made from yellow variety of fermentation length of 3 days are more acceptable than Ogi made from white variety of fermentation length of 5 days. Therefore yellow Ogi has highest percentage protein, Water
Absorption Capacity, odour, colour, texture and overall acceptability by the panelist.

\section{REFERENCES}

Adegoke, G.O and Adebayo, C.O (1994) Production, Nutritional Profiles and Storability of Aadun and Okoro, Two Corn Products Plant Food Hum. Nutr. 45, 139144.

AOAC (2004). Official Methods of Analysis. Association of Official Analytical ChemistsInternational Washington, DC, USA. 
Delcour JA, J Vanstelandt, MC Hythier, J Abecassis (2000). Fractionation and reconstitution experiments provide insight into the role of starch gelatinization and pasting properties in pasta quality. J.Agric. Food Chem. 48: 377-378.

Numfor, F. A., Walter, W. M. and Schwartz, S. J. (1996). Effect of Emulsifiers on the physical properties of Nature and fermented cassava starches. J. Agric. Fd. Chem.44: 2595 - 2599.

Onitilo MO, Sanni LO, Daniel I, Maziya-Dixon B, Dixon, A (2007). Physicochemicaland Functional Properties of Native Starches from Cassava Varieties in SouthwestNigeria. Journal of Food, Agriculture and Environment Vol. 5(3\&4):108-114. SAS (2003). Statistical Analysis Software (SAS) Systems for Windows, SAS Institute Inc., Cary, NC, USA (2003).
Sanni L, M. Onitilo, O.B. Oyewole, T. Keiths, A. Westby (2004). Studies intoProduction and Qualities of cassava grits (Tapioca) in Nigeria. Paper presented atthe sixth International Scientific Meeting of the Cassava Biotechnology Network, 8-14 March 2004, CIAT, Cali Columbia.

Sosulski, F.N. (1962). The centrifuge method for determining starch absorptivity in hard red spring wheat. Cereal Chem. 39:344-346.

Takashi, S. and Seib, P. A. (1988). Paste and gel properties of prime corn and wheat starches with and without native lipids. Cereal Chemistry 65:474.

Williams PC, Kuzina FD, Hlynka L. (1970) A rapid calorimetric procedure for estimating the amylose content of starches and flour cereal chem. 47 (4) 411. 